I 7

\title{
University presses and academic publishing
}

\author{
S A M A N T H A J. RA Y N E R
}

Academic publishing, as John Thompson claimed in 2005, 'has become one of the terrains on which the logics of two different worlds - the world of publishing and the world of the academy - come together and clash, leading on occasion to tension, misunderstanding and mutual recriminations'. 'As this implies, however, there hasn't always been such a tension between the two sides, and this chapter maps out the history of academic publishing in the hundred years between I9I4 and 20I5, looking at the changing research landscape and the ways university presses and commercial academic publishers have engaged with it. Academic publishing is a rapidly developing and changing area: this chapter comes with the caveat that anyone interested in learning about the most up-to-date news should consult sources such as The scholarly kitchen. ${ }^{2}$

In the period following the First World War, the number of universities in Britain began to grow rapidly. In I9I8 there were just over twenty universities and university colleges in the $\mathrm{UK}^{3}$ By the end of the ra6os this figure had more than doubled, the result of the Robbins Report of 1963 which recommended a major expansion of the British university system. ${ }^{4}$ By the end of the I990s the Further and Higher Education Acts of 1992 had given polytechnics university status, and the number rose sharply again; today there are well over one hundred. ${ }^{5}$

At the start of the period under consideration universities could be described as serving 'a small social elite', and attendance, even until the

I Thompson, Books in the digital age, p. I75. 2 https://scholarlykitchen.sspnet.org.

3 Made up of the so-called 'ancient' universities of Oxford, Cambridge, St Andrews, Aberdeen, Glasgow and Edinburgh, and the initial wave of 'red-brick', civic universities - the University of London, Durham, Birmingham, Liverpool, Manchester, Leeds, Sheffield, Bristol and the University of Wales.

4 Universities formed during this time are often referred to as 'plate glass', after a phrase coined by Michael Beloff. Beloff, The plateglass universities.

5 www.universitiesuk.ac.uk/aboutus/members/Pages/default.aspx. 
I950s, was still only about one in twenty-five of each generation. At the beginning of the twenty-first century it was one in two. ${ }^{6}$ This expansion fuelled a corresponding rise in the demands made on academic publishers to disseminate research, a demand that intensified after the introduction of the Research Assessment Exercise in 1986. The range of subjects being taught and studied increased dramatically as disciplines such as psychology, management, media studies and education became part of the curriculum. Publishers had to respond to all this, and master the new digital production workflows that began to impact on business models and dissemination of scholarly communication in the latter half of the twentieth century.

The dominant university presses in the UK throughout the period 19I42015 are Oxford and Cambridge: Oxford University Press is by far the larger of the two, turning over more than three times what its rival does. ${ }^{7}$ Arguably these are also the most stable presences over the decades, as other presses fold, are bought out, or are born. In the first half of the century, these two kept company with university presses such as Liverpool (I899), Manchester (1904) and the University of Wales (I922), along with Edinburgh (I940s), Leicester (1952) and Athlone, for the University of London (1948). Competition for content is widening as new open access initiatives enter the market. ${ }^{8}$ However, commercial academic publishers, operating alongside the university presses, have often demonstrated that they can be as successful (and in many instances more so) than their university-based counterparts.

At the time of the First World War, Oxford University Press was an institution that managed its own paper mill, printing house and publishing business, this last being split between the Oxford site in Walton Street and the London Office in Amen Corner. It was run 'less like a single company and more like a feudal state' ${ }^{\text {, }}$ with continuous tensions between the Printer, the Secretary and the Publisher. Decisions on what scholarly texts were to be published were approved by the Delegates, but on the basis of summaries and recommendations prepared by senior editors. ${ }^{\text {IO }}$ While the Oxford side concentrated on the scholarly outputs, the London office was free to publish more commercial, general interest books, and, under the aegis of the publisher Humphrey Milford, ${ }^{\text {II }}$ expanded to include children's books, poetry and

\footnotetext{
6 Anderson, British universities past and present, p. I.

7 Clark and Phillips, Inside book publishing, fifth edition, p. 67.

8 For example Ubiquity Press, founded in 20I2, and Open Book Publishers, begun in 2008.

9 Whyte, 'Oxford University Press, I896-I945', p. 72.

Io Louis, 'The Waldock Inquiry', p. 767.

II Milford held the job of Publisher from I9I3 to I945.
} 
music, as well as an Overseas Education Department. ${ }^{\mathrm{I2}}$ At Cambridge University Press, which also had an office in London, the management was very different, with the Syndics responsible for financial matters as well as choosing the books to be published. ${ }^{13}$ This was still a time when scholarship, as well as publishing, was considered a genteel calling: at Oxford, just before the First World War, two men who were to become key players in publishing of this period, Basil Blackwell and Geoffrey Faber, joined the University Press. Blackwell is quoted as saying that his time at the Press gave him a lasting impression 'of reverence for scholarship and enthusiasm for any books which might advance its cause'. ${ }^{14}$ Faber's experience was less happy, and he did not stay very long at the Press. One of his memories of working for OUP was that, on requesting whether he might learn something about book production, he was told by Humphrey Milford, then Assistant Publisher in the London Office, that 'a first-class man is a Greek among the barbarians' ${ }^{15}$ The implication was that such direct interaction was frowned upon: practical knowledge of production was not what gentlemen publishers in the early twentieth century needed to know about, as it was still so distinct from the rest of the business.

These attitudes were beginning to change, however. In contrast, publishers like Macmillan, Allen \& Unwin, Methuen or Blackie \& Sons were less hampered by these attitudes and working practices. They developed their own lists in different academic areas: Blackie, for instance, from 1920 'embarked on a world-class list of scientific books at the cutting edge of research that eventually became the strongest British publishing list in the area from a commercial publisher. ${ }^{16}$ When Stanley Unwin took over George Allen \& Sons in 1914, he began to cultivate new authors, and philosophy books in particular emerged as a key focus: Bertrand Russell's works helped build this list. In the field of literary studies, Chatto \& Windus's impact was so strong after 1930 that it has been claimed 'there can rarely have been such a close and sustained association between a publisher and an individual discipline' ${ }^{17}$ Meanwhile, the Macmillans were busy: 'in the midst of the I9I4 war, even the large scale books came out as they always had'. ${ }^{18}$ The Macmillan firm adapted, and this period 'was remarkable not only for the number and weight and authority of the books, political or economic, which expressed the thoughts of the times, but for the area of diverse opinion

I2 See Chapter 3I for information on OUP overseas. I3 McKitterick, A history.

I4 Sutcliffe, The Oxford University Press, p. I63. I5 Ibid., p. I68.

I6 Stevenson, Book makers, p. 78. I7 Collini, 'The Chatto List', p. 636.

I8 Morgan, The house of Macmillan, p. 218. 
covered by those books'. ${ }^{19}$ The Macmillan family were well connected, and could still compete with the university presses for academic works: Herbert Gladstone, J. M. Keynes and A. C. Benson were just a few of their authors in the early part of the twentieth century. Sir Frederick Macmillan had passed on the running of the company to younger family members, and this helped propel it through the uncertain inter-war years. The other major trade publishers who produced academic titles, Longmans and John Murray, were also seeing moves at the top of their companies, so the period was characterised by changes in management, and in some cases commissioning direction, throughout the industry.

Academic publishing grew via new companies, too: Geoffrey Faber, having left OUP, founded Faber \& Gwyer in 1925, followed by Faber \& Faber in 1929. In a speech to booksellers in 193I he made clear that he believed that the bad times people were facing would force them to 'ask themselves all kinds of questions that only books can answer'. ${ }^{\circ}$ He predicted 'a revival of seriousness ${ }^{21}$ and to meet this demand concentrated on developing a literary and non-fiction list that, with the help of T. S. Eliot and Richard de la Mare, built the firm's reputation for marrying 'commercial and literary judgement in an unique and highly original mixture'. ${ }^{22}$ The poetry list, for instance, was a successful part of Faber's broader academic publishing contexts: as Stevenson has noted, 'much of what we would today describe as academic publishing was in the rozos and earlier classified as "general" on the lists of trade publishers. ${ }^{23}$ Firms like Blackwell's also emerged in the early twentieth century, with Basil Blackwell building on an annual series of poetry books that published work by W. H. Auden, Stephen Spender and Louis MacNeice, then through ventures like an Oxford University magazine called Oxford Outlook (which ran for nearly twenty years), and on to scholarly reprints of works such as the plays of George Etherege. Soon academics brought new work to be published, and Virgilian studies became a specialism. ${ }^{24}$ Other new publishers, like Gollancz and Cape, were to produce high-quality books that crossed over into academic areas: this was, despite the complex economic climate, a strong era for publishing in general, and for academic books in particular.

Publishers such as Nelson Thornes took advantage of the growing demand for educational books, and, as the Second World War receded, even more mainstream general publishers like Penguin followed suit with cheap but

I9 Ibid., p. 225. 20 Faber, A publisher speaking, p. 56. 2I Ibid., p. 57.

22 Stevenson, Book makers, p. 7I. 23 Ibid., p. 77. 24 Norrington, Blackwell's, p. 66. 
well-edited classic texts, ideal for students, via series such as their Pelican and Penguin Classics lists. 'These high class Pelicans are a real nuisance', complained Arthur Norrington in 1952, when he was Senior Administrative Officer of Oxford University Press, ${ }^{25}$ and it is not hard to sympathise with his concerns: in 1952 Allen Lane's assets were valued at nearly $£ 215,000 .{ }^{26}$ It has been argued that 'university presses ought to have been in a privileged position to exploit the hectic development on their doorsteps, but the commercial publishers were quicker off the mark. ${ }^{27}$ Pelicans and the Penguin Classics lists were edited by experts, looked fresh and appealing, and were cheap. Penguin both reprinted books in paperback, like E. M. W. Tillyard's The Elizabethan world picture (1942) which had been formerly published in hardback by Chatto, and published new titles, such as E. V. Rieu's translation of Homer's Odyssey, which went on to sell over 3 million copies and 'form the foundation stone of the Penguin Classics'. ${ }^{28}$ University presses, whose production values were different, could not immediately compete with such an adversary, but series such as the Oxford World Classics and J. M. Dent's Everyman's Library, published originally in hardback, would eventually move to the cheaper paperback format to compete more effectively. ${ }^{29}$ In 1957 Cambridge University Press published Brian Pippard's Elements of classical thermodynamics simultaneously in paper and hardback, believed to be the first example of this in the academic market. ${ }^{30}$

However, this took time. The university presses moved within their own traditional working practices, and although they were expanding internationally, and evolving with the new demands these additional territories were giving them, by the mid-twentieth century things were still dominated by earlier patterns. When Michael Black joined Cambridge University Press in 195I, he commented: 'I had joined not just a business, or a university department, but a class - indeed a caste. ${ }^{3 \mathrm{I}}$ The men (for they were largely male) he worked alongside,

were mentally and spiritually at one with other groups which were running the country, the services and the colonies. They had a common ethos as well as common habits. One most striking thing about them is that although to their enemies they seemed class-ridden, they were in fact open to new talent,

25 Ibid., p. 273. 26 Lewis, Penguin special, p. 268.

27 Sutcliffe, The Oxford University Press, p. 272. 28 Lewis, Penguin special, p. 25I.

29 Twenty-four Oxford Paperbacks appeared in 1960, including A preface to 'Paradise Lost' by C. S. Lewis, The Roman revolution by Ronald Syme, and E. J. Dent's Mozart's operas. Flanders, 'The Press in London', p. I74-5. Everyman paperbacks first appeared in I960. Rose, 'J. M. Dent and Sons'.

30 McKitterick, A history, p. 324. 3I Black, Learning to be a publisher, p. 6. 
knew that they depended for success and continued life on getting it - or the cleverest of them did. $^{32}$

For academic publishing this was key, for as the spread of other universities continued to rise in the I950s and I960s, so too did the prevalence of the non-Oxbridge scholars, and the pool of available research material and platforms to publish that came with them. Not only were there more scholars, there was more awareness of the need to accommodate the demands of the modern age, where technology and convenience were replacing the slower, more traditional production methods of earlier in the century. This openness to new ideas helped to move both the Oxford and Cambridge presses to the next phase in their development. Production methods, for example, were updated, replacing Monotype with litho methods: by 1978 letterpress had practically disappeared from OUP altogether. ${ }^{33}$ The Delegates and the Syndics were aided by an expanded and increasingly female staff, who oversaw the growth of the businesses through the post-Second World War expansions of the university and publishing sectors. ${ }^{34}$

The I960s saw the publication of the Robbins Report, which called for more university places for able students. The result was an increase in universities across the UK, and an optimism about the future of scholarship: this 'exuberant innocence' 35 was not to last, but while it did significant developments occurred, not just in the way university education was configured but also in the ways academic books were produced and consumed. This Report impacted directly on academic publishing: Robbins was critical of both Oxford and Cambridge for failing to meet the economic and social needs of post-war Britain. Oxford's response was twofold, via the Franks Report (begun in 1964), which examined the University itself, and the Waldock Inquiry, which looked specifically at Oxford University Press. The Waldock Inquiry concluded in 1970, and advised that the Press should continue to expand and diversify. Although the conclusions were not severely damaging to the Press, this did have far-reaching consequences: the abolition of Perpetual Delegates, and increase in the number of Delegates from ten to fifteen, and full financial disclosure. But perhaps its greatest significance is 'that the work of the committee reflected the rationale for

32 Ibid., pp. 6-7. 33 Maw, 'Printing technology, binding, readers, and social life', p. 289.

34 See copies of The Clarendonian, OUP's in-house staff magazine, for a glimpse into how the gender balance (and hence working and social activities) changed at the Press after the Second World War.

35 Halsey, Decline of donnish dominion, p. I. 
reforms already under way and modernization at a particular time, May $1970^{\circ} .^{36}$

In the USA and other territories, as in the UK, universities were on the rise, and the UK Presses were keen to have stakes in these markets. By the I96os, so significant was this wave of new institutions and potential markets that it was claimed that a major academic library was opening every week in the USA, and that 'future economic historians of the book trade will be able to demonstrate that never since Gutenberg had edition-sizes of learned and academic books been so large, or the market so receptive'. ${ }^{37}$ This was a decade of abundance, and in the world of academic publishing in the UK, as elsewhere, the I96os seemed to promise prosperity for all:

In scholarly publishing, the expansion of higher education throughout the world, the increasing dominance of English as a world language, new investment in the sciences and the re-examination of educational practices more generally brought demand on a scale and at a pace the was simultaneously welcome and perilous. ${ }^{38}$

These were the times for universities to grow, and other university presses along with them. It is no coincidence that during this period enterprises such as the University of Exeter Press and Edinburgh University Press were launched: in 1962 there were II9,000 full-time undergraduates in the UK, and by $1969,219,000 .^{39}$

Academic publishers also became far more export-focussed during this period, as the US and Asian markets opened up, and as these territories became an increasing source for sales and content. John Thompson has undertaken a detailed and thorough analysis of the history of academic publishing during this period, and although his focus is as much on US as on UK publishers, this is helpful in a climate where both markets are increasingly linked by international expansions by the major UK presses. He makes the point that during the I960s and I970s the two countries underwent similar changes. Both benefited from the baby boom and the relatively high domestic economic growth rates of the times, and this phenomenal increase, coupled with the fact that in the 1960s more new members of faculty were taken on than in the entire 325-year history of American higher education up to that point, caused the university presses

36 Louis, 'The Waldock Inquiry', p. 789. 37 Black, Cambridge University Press, p. 227.

38 McKitterick, A history, pp. 375-6.

39 Halsey, Decline of donnish dominion, p. 93. The number of US undergraduates increased by 500 per cent between 1945 and 1975 , making this the golden age of higher education. Thompson, Books in the digital age, p. I8I. 
to hold a justifiably optimistic outlook. The period of growth was even honoured by President Jimmy Carter: in the summer of 1978, he proclaimed a University Press Week 'in recognition of the impact, both here and abroad, of American University Presses on culture and scholarship'. ${ }^{40}$ The presses fulfilled a vital scholarly function: as the number of scholars increased, so too did the need to publish. However, this was not paralleled in the UK. Here, the I970s saw the post-war prosperity fail, as traditional industries like engineering, shipbuilding, textiles and motor manufacturing could no longer compete with other countries. Unemployment rates climbed under Edward Heath's Conservative government, and inflation - and industrial unrest - rose. Britain joined the European Economic Community in 1973, which had implications for business management, and Irish Republican Army bombing attacks brought the fear of war back into people's minds. As Stevenson points out, this all contributed to an environment where, for only the second time since records were kept, fewer new books were published in 1975 than in $1974 .{ }^{4 \mathrm{I}}$

For academic publishing, as with publishing more generally, this decade saw the map shift as London became too expensive as a main base, so companies like Longman, Macmillan, Allen \& Unwin and Butterworth had all moved out of the city by 1973. This strategy enabled them to continue to grow, but was not an option so easily available to the two main university presses. Cambridge University Press suffered the most, as it differed from its Oxford counterpart in having all parts of the business integrated together: 'Whether in commissioning, printing, publishing or in the balance-sheet, the Press's success or failure was ultimately judged not by any one of its activities, but by the whole. ${ }^{42}$ Bentley House, the Press's London base, was shut in 1978. Oxford University Press, in the wake of the Waldock Inquiry, reorganised too: it moved all London activity to Oxford in 1976 , and streamlined the business into new divisions. ${ }^{43}$ It was a mark of how great the challenge to the university presses from their trade opposites had become that the first contracts for publishing for the newly established Open University went to Macmillan in $1970 .{ }^{44}$

40 Quoted on the website of the Association of American University Presses, www.aaup net.org/about-aaup/aaup-history.

4I Stevenson, Book makers, p. 205.

42 McKitterick, $A$ history, p. 375. See the rest of this chapter, 'A developing crisis', for a full description of what happened.

43 The International Division, the UK Publishing Services Division, the Academic Division, the Education Division and the General Division. Sutcliffe, The Oxford University Press, p. 288.

44 McKitterick, 'Looking further', p. 812. 
However, other significant developments show this period reflecting a growing sense of academic publishers as a set of organisations with a distinctive set of common challenges. The University of Toronto Press's establishment in 1969 of the journal Scholarly Publishing is one such indicator. In the first editorial, Marsh Jeanneret highlighted the tendency of institutions to ignore university presses when installing new information systems, and the implications in terms of profit loss and operation. ${ }^{45}$ It is worth noting that this is very much a concern of academic presses in the twenty-first century, too, as open access publishing initiatives complicate the business models of established presses. In addition, the Association for Learned and Professional Society Publishers was set up in 1972, and the Society for Scholarly Publishing in 1978: clearly responding to the need for academic publishers to have professional bodies to represent them.

As the 1980 s began, economic recession in the UK and withdrawal of levels of government funding to higher education meant that the presses were going to have to adapt again in order to survive. While libraries were well resourced, and there was a market for the specialist monograph, the system worked, but as economic pressures began to be felt the university presses turned to more lucrative textbook publishing to bring in additional revenue, and the monograph market began to wane. Thompson explains this situation by pointing to the financial pressures faced by research libraries as university budgets were cut, coupled with the growing proportion of the remaining budget for periodicals and content in electronic formats. ${ }^{46}$ By the 199os, the Society of College, National and University Libraries (SCONUL) reported that between the academic years of 1991/92 and 1999/2000 the percentage of books bought had dropped from 40.2 per cent to 32.6 per cent, while electronic texts rose from 2.3 per cent to ir.5 per cent. ${ }^{47}$

The future of scholarly publishing, a report produced by the Modern Languages Association of America in 2002, explored this past and continuing tension between the university presses and the institutions with which they worked, emphasising that while these budget cuts were being made tenure standards had risen, which created an impossible situation long-term. ${ }^{48}$ In the UK, the introduction of the first Research Assessment Exercise (RAE) in 1986 meant that conditions quickly mirrored those of the USA: the publication of academic research was made a key performance indicator for universities, and this has inevitably continued to build with each successive round of

45 Jeanneret, 'Universities as publishers', p. 3.

46 Thompson, Books in the digital age, p. 99.47 Ibid., p. I04.

48 The future of scholarly publishing, p. I72, https:/ / apps.mla.org/pdf/schlrlypblshng.pdf. 
assessment. As will be seen below, as the open access debates escalated in 2015, publishing and academia in the UK were facing a major challenge, as new mandates from bodies such as the Higher Education Funding Council for England (HEFCE) started to impact on the whole ecosystem that makes up the production and consumption of academic books.

In the 1990s, bookselling changes affected the publishing marketplace, too. ${ }^{49}$ With the abolition of the Net Book Agreement in 1997 and the growing strength of a few large bookselling companies, it was a time of strong sales for academic books, as more titles were sold through shops like Blackwell's and James Thin where stock could be bought centrally and then held on shelves throughout the chains. However, these chains would soon be under threat from the rise of the online bookshop. In 1995, Amazon opened for business in the USA, and by 1998 it had arrived in the UK. It was the beginning of the online shopping age, and 'the university presses and many smaller publishers found that Amazon would quickly become one of their most important accounts'. ${ }^{50}$ Amazon's impact went beyond how academic publishers could sell books via their platform, however: it also helped transform what the publishers could sell. The powerful search facility it offered, alongside increased efficiencies of short-run printing, meant that titles were more discoverable and accessible than ever before. But, as Thompson also points out, Amazon and other 'e-tailers' soon started extending the used book market too, which impacted in negative ways on sales of new books.

This was also a period of mergers and acquisitions in academic publishing: the Macmillan Group was bought by the German group Holtzbrinck in 1995 , Routledge was bought by Taylor \& Francis in 1998, and Pearson acquired Simon \& Schuster in the same year. These mergers meant that by the end of the twentieth century academic publishing business models were changing, not just from the need to restructure internally, but in response to higher education developments and to the rapid rise of computers and electronic technologies. The Dearing Report of 1997, the first review of higher education in the UK since Robbins, made eight key suggestions: full-time undergraduates should contribute $£ \mathrm{I}, \mathrm{ooo}$ per year of study after graduation on an income-contingent basis; there should be a return to the expansion of student numbers; the world-class reputation of UK degrees must be protected; higher education should make greater use of technology; the government should increase funding for research; there should be more professionalism in university teaching; there should be a stronger regional and community

49 See also Chapter 6. 50 Thompson, Books in the digital age, p. 73. 
role for universities; and there should be a review of pay and working practices of all staff. ${ }^{51}$

At the time, universities were underfunded and, as Dearing himself said, 'The crisis in 1996 was the result of a period of very fast growth in student numbers, financed in very substantial part by severe reductions in the unit of resource [the amount a university spends on each student] for teaching, and massive decay in research infrastructure. ${ }^{.52}$ As a result, library resources were cut, and students bought fewer textbooks and supplementary texts. Photocopying, and more judicious textbook buying habits by students, meant sales dropped, along with the increased modularisation of courses which meant books were useful more transiently than previously, when core texts would be used substantially as part of degree courses. ${ }^{53}$

In 201 I the Association of American University Presses (AAUP) produced a report, Sustaining scholarly publishing: new business models for university presses. This document, which represented the outcomes of discussions by university presses from all around the world, including those from Cambridge and Oxford, attempted to explain what had passed, what was happening in the present, and what could and should happen in the future. 'Publishers were essential to the scholarly ecosystem of the pre-web age', the report says, because 'for scholars to see their work disseminated within their scholarly community, it had to be published by a publisher. ${ }^{54}$ But now, in an age of information 'hyperabundance', publishing is within everyone's reach: 'Raw dissemination is now so easy that anything, and everything, can be "published" online - made available to Google, and Bing, and that moment's Twitter feed.' Rather than see this as a threat, however, the Report asserts that:

The scholarly enterprise is in it for the long haul, not the next viral hit. As such, the scholarly ecosystem - libraries, universities, scholarly publishers, scholars - needs to ensure that the entire ecosystem remains strong over time, and that scholarship is well served by the systems we construct. ${ }^{55}$

Partly in response to this context, new initiatives were created, among them the Journal of Scholarly Publishing (a relaunch in 1994 of Scholarly Publishing),

5I John Crace and Jessica Shepherd, 'The right prescription?', Guardian 24 July 2007, www .theguardian.com/education $/ 2007 / \mathrm{jul} / 24 /$ highereducation.tuitionfees.

52 Quoted in ibid.

53 Thompson, Books in the digital age, pp. 272-5, for a discussion of this shift.

54 Sustaining scholarly publishing, p. 6, available at www.aaupnet.org/policy-areas/futureof-scholarly-communications / task-force-on-economic-models-report.

55 Ibid. 
the Scholarly Kitchen, the blog of the Society for Scholarly Publishing, in $2008,{ }^{56}$ and the Association of European University Presses (AEUP), founded in $2010 .{ }^{57}$

In Britain, the Working Group on Expanding Access to Published Research Findings, chaired by Dame Janet Finch, delivered their Report, Accessibility, sustainability, excellence: how to expand access to research publications, in 2012. ${ }^{58}$ In this, so-called 'gold' open access publishing was recommended for academic journal articles: that is, where the funding for the article is paid up front to the publisher by the author, or author's institution, and then the work is made available via an online platform. The Finch Report has accelerated efforts to try and create robust new models for scholarly publishing via open access, for example by working more closely with libraries to make free online access to books, with a print on demand service attached, so that books can be bought if required; by aggregating content via online platforms; and by creating new university presses. Initiatives such as JSTOR (started in I995 and short for Journal Storage) now offer monograph access as part of their services, while Project MUSE (started in 1993 by the Johns Hopkins University Press and the Milton S. Eisenhower Library at the Johns Hopkins University) has offered e-books as well as journals since 2010. Oxford University Press released University Press Scholarship Online in September 20II, and Cambridge University Press launched University Publishing Online one month later. ${ }^{59}$

There were casualties: Middlesex University Press closed in 2009, and Northumbria University Press had a management buy-out - all titles are now owned by McNidder $\&$ Grace. But there are signs that there is a growing place for new university presses too, including some from the newer universities: in 200I the University of Chester Press began; Liverpool University Press was relaunched as a limited company in 2004; and in 2009 Kingston University Press announced it was open. ${ }^{60}$ Others, like Liverpool University Press and Nottingham University Press, have found success and built reputation in niche areas such as gypsy studies and science fiction. In addition, the trade companies diversified, with publishers such as Bloomsbury starting a Bloomsbury Academic arm in 2008, under the leadership of Frances Pinter.

56 http://scholarlykitchen.sspnet.org/about. 57 www.aeup.eu.

58 www.researchinfonet.org/wp-content/uploads/20I2/06/Finch-Group-report-FINALVERSION.pdf.

59 www.universitypressscholarship.com and http://universitypublishingonline.org.

60 'Kingston University launches press', Bookseller 6 November 2009, www.thebookseller .com/news/kingston-university-launches-press.html. 
Bloomsbury Academic pulled in lists from elsewhere, such as the Arden Shakespeare and Methuen Drama, to create an imprint that regularly wins awards. ${ }^{61}$ New forms like the short monograph are appearing via initiatives like Palgrave Pivot, and new organisations such as Open Humanities Press, Open Book Publishers, Open Edition, Open Library of the Humanities, Ubiquity Press and Knowledge Unlatched are showing how open access can work successfully via different business models, in addition to other new university presses, from UCL, Goldsmith's and the White Rose consortium, who are focussing on open access publications. ${ }^{62}$

Political moves continue to drive academic publishing debates on both sides of the Atlantic: in December 2012 the US Research Works Act was introduced, and supported by the AAUP. ${ }^{63}$ This argued for the protection of copyright and access to material: a stance which angered many, and which caused dramatic headlines such as 'Academic publishers have become the enemies of science. ${ }^{64}$ In the UK, the government report Innovation and research strategy for growth anticipated the Finch Report and stated that publicly funded research should be available free of charge. ${ }^{65}$ These diametrically opposed stances mean that the next chapter in the story of scholarly publishing is set to be a complex one. This is acknowledged by research funders and councils: in the USA, the Mellon Foundation is supporting several projects under their Scholarly Communications strand, and in the UK, the Arts and Humanities Research Council, in partnership with the British Library, has funded the Academic Book of the Future Project. ${ }^{66}$ This latter built on work of previous initiatives, particularly work done by OAPEN-UK and HEFCE's 2015 Report on Monographs and Open Access. ${ }^{67}$

Open access publishing challenges scholarly publishing from every context: as Geoffrey Crossick, author of the HEFCE report, said, 'from licensing

6I Bloomsbury Academic won Independent Publisher of the Year and Academic \& Professional Publisher of the Year awards in the Independent Publishers Guild Awards 2013, and in the Bookseller Industry Awards 2014: Academic, Educational \& Professional Publisher of the Year.

62 See also Chapter i8.

63 www.congress.gov/bill/II2th-congress/house-bill/3699/text.

64 Guardian I6 January 2012, www.theguardian.com/science/2012/jan/16/academic-pub lishers-enemies-science.

65 Innovation and research strategy for growth, p. 3. Available at www.gov.uk/government/ uploads/system/uploads/attachment_data/file/32450/II-I387-innovation-and-researc h-strategy-for-growth.pdf.

66 https://mellon.org/programs/scholarly-communications and http://academicbookfu ture.org.

67 Particularly OAPEN’s 20I4 Researcher Survey: see http:/ / oapen-uk.jiscebooks.org. For the HEFCE Report on Monographs and Open Access, see www.hefce.ac.uk/pubs/rer eports/year/2015/monographs. 
and copyright to business models and quality, the issues that must be tackled are thorny and numerous' ${ }^{68}$ Richard Brown, past President of the Association for American University Presses and Director of the Georgetown University Press, proposed a metaphor for the current state of university presses as they move forwards 'towards a brave new world of knowledge': he claimed that the future lies in 'communities of practice'. ${ }^{69}$ By this he meant working collaboratively with scholars and librarians, 'the thought leaders and gatekeepers and teachers and students and stakeholders in a variety of disciplines,.$^{70}$ This is essentially, and perhaps reassuringly, a more joined up way of defining what has always been at the heart of the academic publishing world. As Brown admitted, 'communities of practice are not simply about individual and social relationships and information sharing. They also lie at the heart of scholarly communication and serve as the lifeblood of any business model.' These relationships are, he believes, 'utterly essential for the survival and flourishing of university presses, ${ }^{7 \mathrm{I}}$ This is a view underlined by Crossick, who concluded his report by reflecting on the willingness of the academic community to engage with his work: 'It is important that this engagement continues, because there is much to gain by working with the grain, and much to be lost by not doing so. ${ }^{72}$ This, and John Thompson's contrasting comment at the start of this chapter, neatly bookend the changes of the past hundred years or so in academic publishing history: today there is a much broader range of participants in the field, and a greater awareness of the need for all partners, whether academics, librarians, policy makers, booksellers or publishers, to work together to ensure academic research continues to be disseminated widely, to acknowledge the valueadded contribution each makes to the system of scholarly communication, and to innovate collaboratively to protect the future sustainability and availability of that research.

68 Crossick, Monographs and open access, p. 4.

69 Brown, 'University press forum 20II', p. 9. 70 Ibid., p. I3. $7 \mathrm{I}$ Ibid, p. 9.

72 Crossick, Monographs and open access, p. 70. 